\title{
Relevance of Educational Contribution Of Jiddu Krishnamurti In The Present System Of Education
}

\author{
Meeta Malhotra \\ Research Scholar Desh Bhagat University, \\ Mandin Gobindgarh
}

\begin{abstract}
Jiddu .Kishnamurti's influence on the educational ethos of alternative Indian education is immense. Although he was not an educator in the narrow sense of the term, he worked incessantly in the field of education. He is appropriately described as a 'revolutionary teacher who worked tirelessly to awaken people'. He felt that if people could be awakened to their conditioning of nationality, religion and desires, which inevitably leads to conflicts, they might bring a total change in their lives. His concern for 'good society' found expression in the establishment of schools in India and abroad. Krishnamurti's approach to education was highly original and unconventional for them education should aim at the inner transformation and liberation of the human being. The function of education is to help a person from childhood not to imitate anybody, but to be true to his/her own self all the time. Freedom is the basic motto of Education. Krishnamurti emphasised the relationship between Education and society and said that it's only after evolving a sensible policy of "right' education that we can look forward to the formation of better society. In today's context his views on education are of paramount significance. J. Krishnamurti has been an eminent philosopher and educationist of India. The impact of his philosophy on the educational ethos of alternative Indian education has been of an unquantifiable quality, although this is often not visible in the formal components of secondary school education. Krishnamurti was not an educator in the narrow or formal sense of the term, as he had no formal qualifications to either propagate or promote educational goals or establish educational institutions. Krishnamurti has been described as a revolutionary teacher who worked tirelessly to awaken people to awaken their intelligence, to awaken their sense of responsibility, to awaken aflame of discontent and this commitment to awaken the consciousness of people was undoubtedly based on a 'strong moral passion'.
\end{abstract}

\section{Introduction}

The art of education will never attain complete clearance without philosophy, "without philosophy education would be a blind effort and without education philosophy would be cripple". It is an undeniable fact that the great philosophers of all times have been also great educationists. Philosophy gives purpose and orientation to the educational endeavour of individuals.

Education essentially means harmonious development of body, mind and soul and a general training of the character, behaviour and manner. The concept of education has always been developed with times. And the economic, social and political setup a society too had undergone a change. Every worker in the field of education, teacher or supervisor or administrator is being guided perceptibly or imperceptibly by a philosophy which he gained in variety of education and social experiences in his own life. This may be a sound or inadequate philosophy. The scope of Indian philosophy is very wide it may include man such elements concerned with physical, spiritual and mental world which cannot be seen through ordinary eyes. The things which cannot be seen through eyes can be seen through intuition for the perceptions of abstract things "intellectual eyes" are used. Scriptures speak of "spiritual vision" or "divine eyes' which are capable of seeing even the most abstract things and this ability is achieved after a long methodical training of years and by the grace of the almighty. Thus, in the Indian philosophy, perception of both concrete and abstract things has been considered necessary. 


\section{Justification Of The Study}

Of all the problems that India is facing today, there is probably none so pressing, none so urgent as is the problem of education reconstruction. So keeping in mind this problem, certain educational measures are needed for reconstructing Indian education on modern lines. Our government since independence has appointed many commissions and committees to look into the system of education. Almost all commissions and policies stressed value oriented education for the future citizens. Since Jiddu Krishnamurti has contributed much to the educational thought and practice, so the investigator hopes that study of educational philosophy of Jiddu Krishnamurti will illuminate the path and enlarge the scope for full thinking along new lines as this thinker has greatly contributed to the meaning and content of educational philosophy which may be distinguished as Indian. His creative ideas will shape our present day conception of the aims and meaning of the educational process to a much larger extent. All this leads to the present study.

\section{Statement Of The Problem RELEVANCE OF EDUCATIONAL CONTRIBUTION OF JIDDU KRISHNAMURTI IN PRESENT SYSTEM OF EDUCATION}

\section{Objectives Of The Study}

- To study the general philosophy of Jiddu Krishnamurti

- $\quad$ To study the educational philosophy of Jiddu Krishnamurti in respect of:

○ Aims of education

○ Methods of teaching

- Role of teacher \& parents

○ Krishnamurti's School System

- $\quad$ To study its relevance to the present system of education.

\section{Procedure of Research}

Krishnamurti was self illuminated philosopher who has delivered his ideas in different form to create new vision in the listeners. His valuable thoughts have been compiled in the shape of books, Audio and visual cassettes. The present study is concerned to the educational thoughts of J. Krishnamurti. In educational philosophy mainly two methods have been used Historical and Descriptive method.

\section{Review of Related Literature}

Cavanaugh (1978) He has observed that meaning of education is to know himself and let the child free in the world. So that he can able to change the world.

Peter B. (1986) in his study revealed that the event of "total insight into what is" irreversible frees the mind from its conditioned state.

Vyas S (1986) in his research found that goodness, responsibility, relationship and love all are associated with life. His study has critically discussed on the idea of J. Krishnamurti on different aspects of education.

Ratnam A. (2013) concluded that Krishnamurti never interested in imposing his philosophy on the teachers. Rather, he challenged them to arrive at wholeness or a holistic approach towards living by their own volition, Investigator points out the possible ways by which wholeness can be developed according to Krishnamurti.

\section{About Krishnamurti}

J. Krishnamurti was born on 11 May, 1895, in Madanapalle in the state of Andhra Pradesh, southern India, close to the Rishi Valley Education Centre, an institution he established in 1928, His father was an official in the Revenue Department of the colonial administration and Krishnamurti was one of his five children. After his retirement from public service, Krishnamurti's Father offered his services to the Theosophical Society in Chennai (then called Madras) in exchange for accommodation for his sons and himself. They eventually moved to Adyar, Chennai, in 1909. In the early years of his youth, Krishnamurti and his brother, Nityananda, were adopted by Dr. Annie Besant, the President of Theosophical Society, who saw certain spiritual qualities in him that set him apart from others. This further resulted in Mrs. Besant and other theosophists proclaiming Krishnamurti as the vehicle for the World Teacher who was coming, in their words, to bring salvation to mankind. 


\section{The 'good society'}

In his pursuit of the 'good society', Krishnamurti emphasised the individual's relationship to society as well as his or her responsibility for establishing the 'good society: 'You are the repository of all humanity. You are the world, and the world is you. And, if there is a radical transformation in the very structure of an individual's psyche, it will affect whole consciousness of man'. This kind of society is clearly a society in which caste, class linguistic and regional divisions would cease to exist. Krishnamurti's emphasis on 'goodness' as the foundation of this new society underlines his lpea for a society devoid of any kind of contradictions or dichotomies.

Krishnamurti seeks to establish schools, as communities of people working together, as a step towards bringing about the 'enlightenment' of human beings.

\section{Right Education}

Education forms a central core of Krishnamurti's world view. In fact, Krishnamurti spent his entire life talking about education as being the agent not only of inner renewal but also of social change. Education is therefore the foundation on which the good society will build itself. Krishnamurti always asserted the individual's responsibility to the social order: 'you are the world'. One individual's action therefore affects another, since 'to be is to be related' and in this sense there is no individual consciousness, but only a collective human consciousness which implies that the world is not separate from the individual. Krishnamurti points to the harmonious development of the inner and outer world of an individual: 'what one is inwardly will eventually bring about a good society or the gradual deterioration of human relationship'. Education is not only learning about academic subjects but to educate one self. There is no need to education. It is not that you read a book, pass an examination and finish with

education. The whole of life, from the moment you are born to the moment you die, is a process' of learning. Krishnamurti's schools did not exist as organisations for the indoctrination of children, but rather as places 'where students and teachers can flower, and where a future generation can be prepared because schools are meant for that. The notion of 'flowering' here implies an unfolding of the consciousness of individuals in relationship to one another in educational praxis. The psychological development of individuals is therefore as important as acquiring academic knowledge and skills. The Intention of the Krishnamurti Foundation India schools is that they 'are not only to be excellent academically but are to be concerned with the cultivation of the total human being.

The role of 'right education' is to make the individual highly sensitive to everything not just to mathematics and geography because the highest form of sensitivity is the highest form of intelligence'. For Krishnamurti, therefore, the right kind of education does not simply produce engineers, doctors or scientists, but a 'human being who is alive, fresh, eager. If one is a human being, one is not a specialist, but a total entity'. An 'educated mind' is one that thinks that is active, alive; it is a mind that looks, watches, listens and feels.'

\section{Krishnamurti Schools}

Education was always one of Krishnamurti's chief concerns. He felt that if only the young and the old could be awakened to their conditioning of nationality, religion, prejudices, fears, and desires, which inevitably leads to conflict, they might bring to their lives a totally different quality. His concern found expression in the establishment of schools in India and abroad.

When Krishnamurti spoke to school children, his language was lucid and simple. He explored with them, their relationship to nature and to one another, and to psychological problems like fear, authority, competition, love and freedom. To him the schools were a milieu in which the larger existential issues could be explored in an atmosphere of freedom and responsibility.

The more apparent features of this spirit are shared by all schools-large campuses of great natural beauty, a friendly, caring relationship between teachers and students, simple, wholesome vegetarian diet, austere but comfortable living quarters; spacious and inviting classrooms well-equipped libraries laboratories ; and a small teacher-student ratio with highly qualified and motivated teachers. The official Krishnamurti Schools are:

- USA-Oak Grove School

- UK-Brockwood Park School

- India-Rishi Valley Education Centre 
- India-Rajghat Education Centre Rajghat Fort

- India-The School "Damodar Gardens"

- India-Bal Anand, Mumbai India-The Valley School Bangalore Education Centre

- India-Sahyadri School

Surely, a school is a place where one learns about the totality, the wholeness of life. Academic excellence is absolutely necessary, but a school includes much more than that. It is a place where both the teacher and the taught explore not only the outer world, the world of knowledge, but also their own thinking, their own behavior.

It is only in such freedom that true learning can take place. In this school it is the responsibility of the teacher to sustain with the student a careful exploration into the replications of conditioning and thus end it. A school is a place where one learns the importance of knowledge and its limitations. It is a place where one learns to observe the world not from any particular point of view or conclusion; one learns to look at the whole of man's endeavor, his search for beauty, his search for truth and for a way of living without conflict. So far education has not been concerned with this, but in this school our intent is to understand actuality and its action without any preconceived ideals, theories of beliefs which bring about a contradictory attitude towards existence. The school is concerned with freedom and order.

The focus at these schools is therefore not only on academic excellence but also on trying to develop and nurture a different quality of mind that will be in harmony with the external world.

\section{Krishnamurti's approach to the nature of education}

\section{The intentions of education}

For Jiddu Krishnamurti, the intentions of education must be the inner transformation and liberation of the human being and, from that, society would be transformed. Education is intended to assist people to become truly religious. These intentions must not be just pleasant sounding ideals to which one pays lip service, and they are not to be arrived at by their opposites. And the religious intentions are not for some eventual goal, but for life in educational centers from moment to moment.

\section{The physical nature of the places of education:}

(a) Aesthetics: The schools Krishnamurti founded are very beautiful places, and this is not by accident. Beauty is important, not just because it is pleasing, but because sensitivity to beauty is related to being religious and indispensable to the healthy growth of a child.

Perhaps we should include in this discussion aesthetics what Krishnamurti felt about nature and education. This makes sense in that, for Krishnamurti. nature was both beautiful and a demonstration of order. The educational centers Krishnamurti founded are invariably in parks or countryside. This was not just because he felt that nature was pleasing, but because he felt that a relationship with nature had important implications for living sanely and to a relationship with the sacred. He would not, however, condemn as hopeless, innercity schools that don't have such luxuries, because nature was wholly available in the smallest part; a blade of grass, a house plant, or a gold fish. If you establish a relationship with nature then you have relationship with mankind.... But if you have no relationship with the living things on this earth you may lose whatever relationship you have with humanity, with human beings.

\section{(b) Special areas that should exist in educational centers:}

Another physical aspect of the educational centers Jiddu Krishnamurti created and another indication of the religiousness of education was his insistence that the schools have special places for silence; He often spoke to the students of the importance of a quiet mind or silence so that they could observe their thoughts.

You see meditation means to have a very quiet, still mind, not a chattering mind; to have a really quiet body, quiet mind so that your mind becomes religious. The mind of a religious man is very quiet, sane, rational, and logical and one needs such a mind.

\section{The Educator}


The right kind of education begins with the educator, who must understand himself and be free from established patterns of thought. If he has not been rightly educated, what can he teach except the same mechanical knowledge on which he himself has been brought up? The problem, therefore, is not the child, but the parent and the teacher, the problem is to educate the educator. If we the educators do not understand ourselves, if we, do not understand our relationship with the child but merely stuff him with information and make him pass examinations. How can we possibly bring abougr a new kind of education? The pupil is there to be guided and helped; but if the guide, the helper is himself confused and narrow, nationalistic and theory- ridden, then naturally his pupil will be what he is and education becomes a source of further confusion and strife.

To educate the educator that is, to have him understand himself - is one of the most difficult undertakings, because most of us are already crystallised within a system of thought or a pattern of action; we have already given ourselves over to some ideology, to a religion, or to a particular standard of conduct. That is why we teach the child what to think and not how to think Krishnamurti expressed his views about education thus:

". . ...and I think the teaching profession is the highest profession in the world. Though one acquires very little money out of it I think it is the greatest thing. Really I do think that. It isn't just verbal rhetorical assertion. It's the greatest thing, because in our hands lie the whole future generation." This is one of the responsibilities of the educator, not merely to teach mathematics or how to run a computer. Far more important is to have communion with other human beings who suffer, struggle, and have great pain and the sorrow of poverty, and with those people who go by in a rich car. If the educator is concerned with this he is helping the student to become sensitive. sensitive to other people's sorrows, other people's struggles, anxieties and worries, and the rows that one has in the family. It should be the responsibility of the teacher to educate the children, the students, to have such communion with the world.

The first thing a teacher must ask himself, when he decides that he wants to teach, is what exactly he means by teaching. Is he going to teach the usual subjects in the habitual way? Does he want to condition the child to become a cog in the social machine, or help him to be an integrated, creative human being, a threat to false values? And if the educator is to help the student to examine and understand the values and influences that surround him and of which he is apart, must he not foe aware of them himself? If one is blind, can one help others to cross to the other shore? As we have pointed out, we are deeply involved in our daily life as educators and human beings.

We are first human beings and then educators: not the other way around. As a human being, with a special profession of education, the teacher's life is not only in the classroom but is involved with the whole outer world as well as inner struggles, ambitions and relationship. He is as conditioned as the student. Though their conditioning may vary, it is still a conditioning. If you accept it as inevitable and abide by it, then you are further conditioning others.

\section{Discipline}

Discipline in schools becomes necessary when there is one teacher to a hundred boys and girls, then you jolly well have to be very strict; but such discipline will not produce an intelligent human being. And most of us are interested in mass movements, large schools with a great many boys and girls; we are not interested in creative intelligence, therefore we put up huge schools with enormous attendances.

To cultivate a good mind, a mind that is capable of perceir.ing the whole of life as one unit unbroken, and so a good mind, it is necessary that all our schools a certain kind of discipline must exist. We must together understand the hated and perhaps despised words 'discipline' and 'rules Discipline means to learn not to conform. If you want to be a good carpenter you must learn the proper tools to use with different kinds of wood and learn from a master carpenter. If you wish to be a good doctor you must study for many years, learn all the facts of the body and its many ways, cures, and so on. Every profession demands that you learn as much about it as you possibly can. This learning is to accumulate knowledge about it and act as skillfully as you can. Learning is the nature of discipline. Learning why one should be punctual to meals, the proper time for rest and so on,is learning about order in life. In a disorderly world where there is much confusion politically, socially, and even in religion, our schools must be centers of order and the education of intelligence. 


\section{Knowledge}

Knowledge must inevitably be superficial. It is the cultivation of memory and employing that memory efficiently and so on. Knowledge being always limited is the function of the teacher to help the student to live all his life only within the limitations of knowledge? We must first realise that knowledge is always limited, as are all experiences.

Is the communication of knowledge the only function of the teacher as it is now passing on information, ideas, theories and expanding these theories, discussing various aspects of them? Is this the only function of a teacher? If this is all a teacher is concerned with, then he is merely a living computer. But surely a teacher has far greater responsibility than this. He must be concerned with behaviour, with the human complexity of action, with a way of his life which is the flowering of goodness. Surely he must be concerned with the future of his students and what is the future of these students? What is the future of man? What is the future of our consciousness which is so confused, disturbed, messy, in conflict. Must we perpetually live in conflict, sorrow and pain? When the teacher is not in communication with the student about all these matters. then he is merely a lively, clever machine perpetuating other machines.

By watching perhaps you learn more than from books. Books are necessary to learn a subject whether it be mathematics, geography, history, physics or chemistry. The books have printed on a page the accumulated knowledge of scientists, of philosophers, of archaeologists and so one.

Most of us in any school, and particularly in these schools, gather knowledge, information, and that is what schools have existed for so far : to gather a great deal of information about the world outside, about the heavens, why the sea is salty, why the trees grow, about human beings, their anatomy, the structure of the brain and so on. And also about the world around you, nature, the social environment, economics and so much else. Such knowledge is absolutely necessary but knowledge is always limited. However much it may evolve, the gathering of knowledge is always limited. Learning is part of acquiring this knowledge of various subjects so that you can have a career, a job that might please you, or one that circumstances, social demands may have forced you to accept though you may not like very much to do that kind of work.

But as we said, you learn a great deal by watching, watching the things about you, watching the birds, the tree, watching the heavens, the stars, the constellation of orion, the dipper, the evening star. You learn just by watching not only the things around you but also by watching people, how they walk, their gestures, the words they use, how they are dressed. You not only watch that which is outside but also you watch yourself, why you think this or that, your behavior, the conduct of your daily life, why parents want you to do this or that.

Learning is extraordinarily important because learning is endless. Learning why human beings kill each other for instance. Of course there are explanations in books, all the psychological reasons why human beings behave in their own particular manner, why human beings are violent. All this has been explained in books of various kinds by eminent authors, psychologists and so on. But what you read is not what you are. What you are, how you behave, why you get angry envious, why you get depressed, if you watch yourself you learn much more than from a book that tells you what you are. But you see it is easier to read a book about yourself than to watch yourself. The brain is accustomed to gather information from all external actions and reactions. Don't you find it much more comforting to be directed, for others to tell you what you should do? Your parents, especially in the East, tell you whom you should marry and arrange the marriage, tell you what your career should be. So the brain accepts the easy way and the easy way is not always the right way. I wonder if you have noticed that nobody loves their work anymore, except perhaps a few scientists, artists, archaeologists. But the ordinary, average man seldom loves what he is doing. He is compelled by society, by his parents or by the urge to have more money. So learn by watching very, very carefully the external world, the world outside you, and the inner world; that is, the world of yourself.

The great poets, painters, composers are never satisfied with what they have done. They are always learning. It isn't after you have passed your exams and gone to work that you stop learning. There is a great strength and vitality in learning, especially about yourself. Learn, watch so that there is no spot that is not uncovered, looked at in yourself. This really is to be free from your own particular conditioning. The world is divided through its conditioning you as an Indian, you as an American. you as a British Russian, Chinese and so on. Out of this conditioning there are wars, the killing of thousands of people, the unhappiness and the brutality. 
So both the educator and the educated are learners in the deeper sense of that word. When both are learning there is no educator or one to be educated. There is only learning. Learning frees the brain and thought of prestige, position, status. Learning brings about equality among human beings.

\section{Teacher Taught relationship}

In India, Krishnamurti appeared a rather forbidding philosopher who advocated no crutches of either a spiritual or an emotional nature and certainly did not: allow any psychological or intellectual attachment to himself as a teacher Moreover, he seemed to be setting a rather difficult task, especially since Hindu tradition in India allows of ritual, belief and unquestioning devotion to a teacher as instruments for psychological, spiritual and social well-being. Krishnamurti's break with tradition and all forms of authority, however, characterises his strength as a philosopher, for he was like a breath of fresh air to those who had been trying to fathom the depths of both consciousness and existence following traditional paths of understanding.

\section{Relevance of Krishnamurti's Education In Contemporary India:}

From 1929, when Krishnamurti declared that his only concern was to set man totally free, 'freedom' as a state of being was central to his view of life. Evidently, he developed his 'celebrated doctrine of freedom against the background of an abiding love of nature and a firm commitment to individual responsibility in working towards a better society and protecting our natural heritage. This is reflected in the strong commitment to the habitat and the environment within the KFI schools, curricular frameworks. It has been suggested that this commitment points to "new policy goals for education in India - goals that give priority to the Indian earth rather than to the Indian nation. This in turn would lead to a new curriculum in Indian schools focusing on 'sustaining' the earth".

Learning, therefore in the KFI schools is not just about ideas or facts in books, but is also about feeling the earth, watching the sunset, teaming to the birds, seeing the colours of the leaves change in the different seasons and observing nature in its many colours, forms and shapes, not as a romantic naturalist but in harmony with what is being observed. From this harmony, a sense of responsibility towards the earth and a commitment towards life on earth will evolve. The KFI School in Chennai has in fact developed a formal curriculum for Environmental Studies as an optional subject at the senior secondary school level, which has been accepted and granted recognition by the Indian Council for Secondary Education (ICSE) for use in all schools affiliated with the ICSE. This has undoubtedly been a major contribution by the KFI schools to the senior secondary school curriculum in India and has wider ramifications in terms of developing the potential for developing a perspective and lifestyle that support ecological balance and emphasize the sustenance of the biosphere. It is true that very few schools in India have included environmental and social concerns directly in the curriculum. There is a component of 'Socially Useful Productive Work" in secondary schools that enables students to engage in a variety of activities, from gardening to community service, on a fixed and somewhat formal basis. It is here that KFI schools have made another contribution to educational processes in term of the school's relationship with the community. Taking the cue from Krishnamurti's emphasis on an individual's relatedness to society, the KFI schools undertake projects with the local community and try to establish a wider network of relating to the community that goes beyond mere 'community service' as an aspect of the formal curriculum.

The consequences of Krishnamurti's view of humanity for education Contrary to the perspective that has shaped much in conventional education, Jiddu Krishnamurti left that all people need to explore themselves and reveal themselves to themselves rather than be shaped into something by others. This is not a new perspective, and again has links to the educational theories of Rousseau, Pestalozzi, Frobel and Montessori. The function of education, then, is to help you from childhood not to imitate anybody, but to be yourself all the time. So freedom lies in understanding what you are from moment to moment. You see, you are educated for this your education encourages you to become something or other. To understand life is to understand ourselves, and that is both the beginning and the end of education. Modern education is making us into thoughtless entities it does very little towards helping up to find our individual vocation. Right education is to help you to find out for yourself what you really, with all you heart, love to do. It does not matter what is, whether it is to cook, or to be a gardener, but is something in which you have put your mind, your heart. 
It is in this context that Krishnamurti's engagement with education is of paramount significance, namely his emphasis on the relationship between education and society in terms of the transformational potential of education. This aspect of Krishnamurti s teachings is the cornerstone of his educational thought and can make a significant contribution to evolving a sensible policy that concerns itself with change through 'right' education.

\section{References}

1. Abhyankar, S. N. (1982). A Study of Jiddu Krishnamurti 's Philosophy Of Educaton. Doctrol Thesis . Retrived From www.shodhganga.inflibnet. ac.in.

2. Belfour, C. (1977). The Boyhood of J. Krishnamurti . Mumbai : Krishnamurti Chetna Private Limited.

3. Byers, P. (1998). Jiddu Krishnamurti Encyclopedia of World Biography. Michigan: Gale Research.

4. Chinnaiah, P. (1994). Jiddu Krishnamurti on Human Preicament and the way out - A Critical Study. Doctrol Thesis, Tirupati : Triputi University.

5. Dhopeshwarkar, A. (1973). Krishnamurti and the Texture of Reality. Mumbai: Chetna Private Limited.

6. Eyres, H. (2005). Rare Retreat Without Restrictions . London: Article in Financial Times.

7. Fourere, R. (1954). Krishnamurti: The Man and His Teachings. Mumbai: Chetna Press.

8. Grohe, F. (1991). The Beauty of the Mountain: Memories of Krishnamurti. Madras: Krishnamurti Foundation Trust.

9. Holroyd, S. (1991). Krishnamurti: The Man, The Mystery and The Message. England: Retrived from http://www.idylwildbooks.com

10. Jayakar, P. (1986). Krishnamurti: A biography (1st Ed.). San Francisco: Harper press.

11. Krishnamurti, J. (2000). Book All the Marvelous Earth. Ojai, America: K. Publications of America. Retrived from http://www.jiddukrishnamurti.net

12. Krishnamurti, J. (1985). The Way of Intelligence. New Delhi: B.I. Publications. 